\title{
Living Standards in St. Louis and the Eighth Federal Reserve District: Let's Get Real
}

\author{
Cletus C. Coughlin, Charles S. Gascon, and Kevin L. Kliesen
}

Recently, the Bureau of Economic Analysis (BEA) has developed the Regional Price Parities (RPPs), spatial price indexes that allow for comparison of cost of living differences across various geographic areas. By construction, RPPs compare the average price level for a region with the national average. Accordingly, unlike traditional, temporal price indexes, RPPs can be used to adjust nominal incomes for cost of living differences, thereby allowing for more accurate comparison of living standards across geographic areas. When adjusting incomes in this manner, the authors find that, despite slow economic growth recently, living standards are relatively high in the St. Louis metropolitan statistical area (MSA). For example, the St. Louis MSA ranks in the top 6 percent of MSAs based on real per capita personal income and in the top 16 percent based on real median household income. (JEL D31, R11, R13, R31)

Federal Reserve Bank of St. Louis Review, Fourth Quarter 2017, 99(4), pp. 377-94. https://doi.org/10.20955/r.2017.377-394

$\mathbf{H}$ eadline measures of economic activity suggest that the performance of the St. Louis economy has been lackluster in recent years. Some authors have even gone so far as to claim that the area's best days are possibly behind it. 1 As Table 1 shows, between 2009 and 2015, real gross domestic product (GDP) per capita in the St. Louis metropolitan statistical area $(\mathrm{MSA})^{2}$ grew at an annual rate of 0.8 percent, less than 60 percent of the nation's growth rate of 1.5 percent per year. Similarly, St. Louis's nonfarm payroll employment grew at an annual rate of 0.7 percent, trailing the nation's growth of 1.1 percent. Nonetheless, during this period St. Louis's unemployment rate declined relatively more than the nation's rate and by more than the rest of the Eighth Federal Reserve District in general. $\underline{3}$

Growth rates, which are sensitive to the period examined, matter for analyzing economic performance. Growth rates, however, do not adequately measure the economic well-beingwhat economists often call living standards - of an MSA's residents at a given point in time. Living standards are typically measured in dollar terms, such as income per person or per household, for a given period (e.g., year). In effect, they measure how much an individual

Cletus C. Coughlin is a senior vice president and chief of staff, Charles S. Gascon is an economist, and Kevin L. Kliesen is a research officer at the Federal Reserve Bank of St. Louis. Andrew E. Spewak provided excellent research assistance.

(c) 2017, Federal Reserve Bank of St. Louis. The views expressed in this article are those of the author(s) and do not necessarily reflect the views of the Federal Reserve System, the Board of Governors, or the regional Federal Reserve Banks. Articles may be reprinted, reproduced, published, distributed, displayed, and transmitted in their entirety if copyright notice, author name(s), and full citation are included. Abstracts, synopses, and other derivative works may be made only with prior written permission of the Federal Reserve Bank of St. Louis. 


\section{Table 1}

\section{Economic Performance of Nation and District MSAs (2009 to 2015)}

\begin{tabular}{lcccc} 
MSA & $\begin{array}{c}\text { Annualized } \\
\text { per capita } \\
\text { GDP growth }\end{array}$ & $\begin{array}{c}\text { Annualized } \\
\text { nonfarm payroll } \\
\text { employment growth }\end{array}$ & $\begin{array}{c}\text { Unemployment } \\
\text { rate (2015) }\end{array}$ & $\begin{array}{c}\text { Change in } \\
\text { unemployment rate }\end{array}$ \\
\hline St. Louis, MO & 0.8 & 0.7 & 5.0 & -4.8 \\
Memphis, TN & 0.2 & 0.7 & 6.2 & -3.8 \\
Louisville, KY & 1.8 & 1.6 & 4.7 & -5.3 \\
Little Rock, AR & 0.3 & 0.6 & 4.5 & -2.2 \\
\hline Eighth District & 0.8 & 1.0 & 4.9 & -4.2 \\
U.S. average & 1.5 & 1.1 & 5.3 & -4.0
\end{tabular}

NOTE: MSAs are labeled based on their principal city. The Eighth District measure is estimated using the sum of all 20 Eighth District MSAs.

SOURCE: BEA, BLS, Census Bureau, and authors' calculations.

can consume. Despite slow economic growth, living standards recently have been relatively high in St. Louis compared with other metro areas. For example, St. Louis's median household income of about $\$ 56,000$ in 2015 ranks in the top third of all 381 MSAs in the United States. Furthermore, adjusting income for the relatively lower cost of living in St. Louis provides a more accurate measure of the purchasing power of this income. 4 Indeed, using cost-of-livingadjusted income measures reveals that St. Louis compares even more favorably with its peers. St. Louis ranks in the top 6 percent of MSAs based on real per capita personal income and in the top 16 percent based on real median household income.

Although headline growth rates and the levels of living standards are different economic metrics, each provides valuable information on the overall health of the economy. Growth rates of real income, for instance, measure the trajectory of economic well-being from a starting point to a terminal point, which allows us to gauge how living standards have changed over time and could possibly change in the future. $\frac{5}{}$ Conversely, looking at income levels allows us to measure the current well-being of an area's residents compared with peers in other areas. Hence, by studying both growth rates and levels, we can better assess living standards across time in St. Louis and more broadly in the Eighth District.

\section{MEASURING LIVING STANDARDS}

To economists, determining living standards at the household or individual level begins with the income earned from employment or, if not employed, retirement benefits or transfer payments. 6 Income is either spent on goods and services or saved to fund future consumption. Households' standard of living depends not only on the dollar value of their income, but also on the prices of the goods and services that they choose to purchase. ${ }^{-}$Indeed, a well-known definition of income growth used by economists is "the increase in the individual's ability to consume during a given period of time." $\underline{8}$ 
Economists must grapple with several issues when measuring living standards for a geographic area, such as an MSA or a state. First, which measure of income should be used? There are several to choose from, such as wages and salaries, total compensation (which includes benefits such as health insurance or contributions to individual and/or company-sponsored retirement plans), per capita personal income (which includes interest income), or household income (an even broader definition of income).. Once the preferred measure of income is chosen, one must decide whether to use average or median income. The top earners in a given area tend to garner a disproportionate share of income. The median income, as opposed to an average, is less affected by this skewness. $\underline{10}$

A second issue is how to adjust income to account for the fact that the prices of goods and services that households consume change over time. 11 If an individual's income rises by 5 percent in a year and the average of all prices rises by 5 percent, then the individual's real income (i.e., the purchasing power of the income) is unchanged. In other words, living standards are unchanged despite nominal income having risen by 5 percent. According to economic theory, a price index should be able to measure a change in the cost of purchasing all goods and services over time relative to some benchmark. These price indexes are termed cost of living indexes. The basic goal of a cost of living index is to determine what percentage of specific goods and services the average consumer purchases each month (the "consumption basket") and then track how the prices of that basket change over time. 12 The consumption basket includes rent, food, medical care, and other goods and services. In this article, our measure of living standards will be nominal income deflated (divided) by a cost of living index.

One consideration for a cost of living index is that prices of goods and services do not all rise at the same time or at the same rate. This fact implies that relative price changes-that is, the change in the price of one good relative to another-can be significant. Such price changes can cause consumers to change their expenditures, which are termed substitution effects. As a result, the expenditure shares, which are termed weights, in the typical consumption basket can change over time. $\frac{13}{3}$ For example, the consumer expenditure shares on medical care goods and services have risen over time, while the expenditure share on food and beverages has declined. There also appears to be sizable variations in non-rent prices between urban and rural areas. This issue will be discussed in greater detail below.

\subsection{Regional Price Parity Indexes}

The best-known national cost of living measures are the consumer price index (CPI) and the personal consumption expenditures price index (PCEPI). The CPI and PCEPI are temporal price indexes because they assess how average prices for the nation have changed over time. Temporal price indexes are also constructed for MSAs; thus, an analyst could gauge the inflation rate (the change in all prices) for the St. Louis MSA by computing the percentage change in the St. Louis MSA CPI or PCEPI between any two periods. However, temporal price indexes are not well suited for analyzing cost of living differences across states or MSAs. ${ }^{14}$ The reason is that they cannot be used to compare price level differences between two areas such as, say, St. Louis and Chicago or between Missouri and Illinois. To analyze the differences in price levels (and, consequently, standards of living) across regions, a spatial price index is required. 


\section{Coughlin, Gascon, Kliesen}

\section{RPPs as Preferred Cost of Living Measure}

The BEA uses location-specific price and expenditure data from the BLS and other sources for many types of goods and services, such as apparel, food, medical, and housing costs. They then use the data to compute RPPs for nine expenditure classes and for all expenditures. Readers seeking technical information should consult papers by BEA economists Aten, Figueroa, and Martin (2011 and 2012). ${ }^{1}$

The RPPs and the Cost of Living Index (COLI) published by the Council for Community and Economic Research (2015) are the most well-known spatial price measures. The RPPs are the preferred measure because they do not suffer from the shortcomings associated with the COLI. The COLI tends to overstate the variation in costs across metro areas for a few reasons. First, it is designed to measure the cost of living for high-income households. Second, the COLI is based on data collected by volunteers on local prices, which can lead to bias. Research by Handbury and Weinstein (2015) has found that food price measures in the sample overstate regional variation in food costs by over 90 percent. Moreover, Olsen, Early, and Carillo (2010) found that, because of few housing prices observations, housing costs tend to be overstated in some high-cost areas.

A problem, however, is that RPPs are available only from 2008 onward. Thus, for studies examining periods prior to 2008, other cost of living measures, such as the one by Olsen, Early, and Carillo, are preferred.

1 The RPPs are updated and published on an annual basis. The data are lagged by a little more than two years. For example, the 2015 RPPs were published in June 2017.

\section{Figure 1}

\section{State-Level RPP Indexes, 2015}

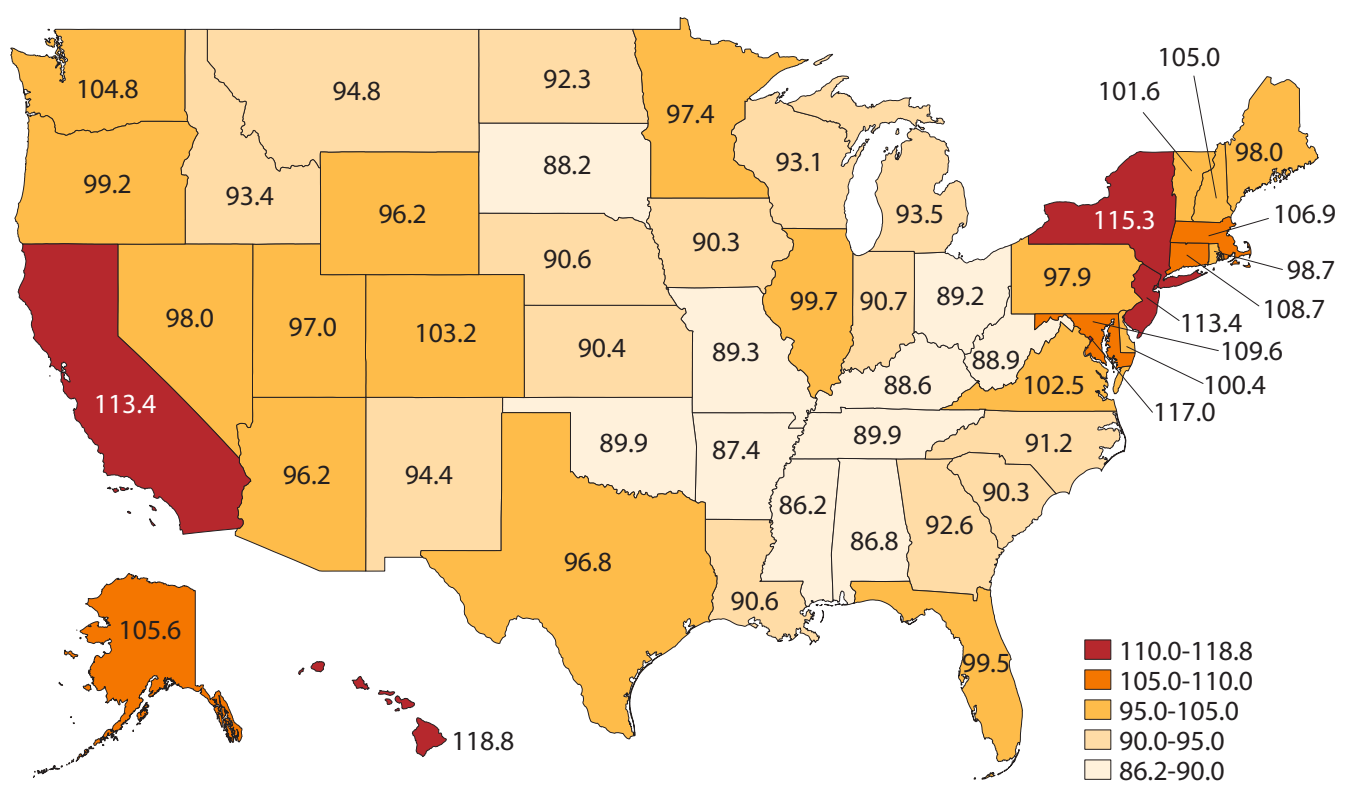

SOURCE: BEA. 
Recently, the Bureau of Economic Analysis (BEA) has developed spatial price indexes that allow comparisons of price levels and thus cost of living differences across various geographies, such as census regions, states, MSAs, and non-metropolitan areas. These BEA indexes are termed the regional price parities (RPPs). (See the boxed insert for more information about the construction of RPPs.) By construction, RPPs compare the average price level for a region with the national average (all areas). This means that the RPP for the nation is 100.

In 2015, 14 states and the District of Columbia (Washington, D.C.) had RPPs above the national average. As shown in Figure 1, the three highest RPPs were Hawaii (118.8), Washington, D.C. (117.0), and New York (115.3). Thus, each of these regions had an average price level more than 15 percent greater than the national average. By contrast, 36 states had RPPs less than the national average (100). Two Eighth District states, Mississippi (86.2) and Arkansas (87.4), have among the lowest RPPs. Missouri's RPP was 89.3; this means that the price level of all goods and services in Missouri was 10.7 percent below the national average in 2015 . We can also examine the distribution of state RPPs at different points in time. $\frac{15}{} \mathrm{In}$ 2009, 17 states and Washington, D.C., had RPPs above the national average, while 33 states had RPPs at or below the national average. As we will discuss in detail later, the most populated states tend to have higher costs of living; as a result, over two-thirds of states have a cost of living below the national average.

\section{THE IMPORTANCE OF HOUSING COSTS IN THE RPPS}

Perhaps the most important consideration in discussions of cost of living across MSAs is that expenditure shares on goods and services can differ markedly across MSAs. Notably, housing, which has the largest weight in the consumption basket, tends to account for the largest differences in the cost of living across MSAs. $\frac{16}{}$ Accordingly, if house prices (and rents) are rising rapidly and housing rent services comprise a large share of the household's consumption basket, then the cost of living in these areas will be rising faster than in other areas for a given level of income.

Housing cost differences are a primary driver in the differences in cost of living across metro areas for three key reasons. First, the value of regional amenities such as the quality of schools (and property taxes) are capitalized into housing prices. This capitalization is reflected mostly in the price of the land. On the demand side, housing values are affected by amenities such as schools, local restaurants, weather, and recreational opportunities. On the supply side, land-use or building restrictions reduce the availability of developed land. All of these factors get capitalized into property values. $\frac{17}{}$

Second, housing is a fixed asset that cannot be easily moved from one market to another. Many other goods and services purchased by households are tradable across vast distances, especially since the advent of the internet. Theoretically, if a television costs more in New York than in St. Louis, a consumer in New York can buy it online from St. Louis. To compete, local New York retailers would have to reduce prices. This economic force, termed "arbitrage," drives prices of tradable goods and services down, leading to little variation in prices across 
Table 2

RPP Expenditure Weights: Selected MSAs, 2015

\begin{tabular}{lccc} 
MSA & Rents & Non-rent services & Goods \\
\hline St. Louis, MO & 19.1 & 37.5 & 43.4 \\
Memphis, TN & 19.7 & 36.7 & 43.7 \\
Louisville, KY & 18.5 & 37.2 & 44.2 \\
Little Rock, AR & 18.8 & 37.1 & 44.1 \\
\hline Average of all MSAs & 22.3 & 37.0 & 40.7 \\
Average of 5 largest MSAs & 24.3 & 38.3 & 37.4 \\
Average of all other MSAs & 21.7 & 36.7 & 41.6 \\
Non-metro areas & 14.3 & 36.7 & 48.9 \\
NOTE: The 5 largest MSAs are New York, Los Angeles, Chicago, Dallas, and Houston. & & \\
SOURCE: BEA and authors' calculations. & & & \\
\end{tabular}

regions. $\frac{18}{}$ Housing, however, is not a tradable good. For example, a household in New York cannot easily purchase a St. Louis home at a lower price and move the house to New York and retain the savings. As a result, housing prices vary more across regions than most goods and services. Other services, such as childcare, would also be considered non-tradable and exhibit regional price differences.

Third, housing is a necessity, so its demand is relatively inelastic. Therefore, as the cost of housing increases, consumers find themselves dedicating a larger share of income toward housing. In effect, shelter is a cost that must be borne by most everyone. That is not to say that substitution effects do not exist. In MSAs with relatively lower per-unit housing costs, consumers are able to buy or rent larger housing units while, overall, devoting a relatively smaller proportion of their income to housing. This implies that consumers who choose to live in areas with high housing costs spend more of their income on housing and proportionately less of their income on other goods and services. Since housing rents drive much of the differences in overall cost of living across metropolitan areas, they can be an effective proxy for the overall cost of living. $\underline{\underline{19}}$

The rent category is designed to measure the cost of providing shelter to a homeowner or renter. For tenants, this cost could be in the form of monthly rent. For homeowners, this would be the monthly mortgage payment. ${ }^{20}$ Table 2 details RPP expenditure weights in 2015 for rents, non-rent services, and goods. These weights are shown for the four largest Eighth District MSAs and then compared with the average of all MSAs, the five largest MSAs (by population), the average of all other MSAs, and the average of non-metro areas. In 2015, the expenditure weight for rent in the St. Louis RPP was 19.1 percent, whereas for all MSAs the average was 22.3 percent. Rent shares in Memphis (19.7 percent) were modestly higher than in St. Louis, but lower in Little Rock (18.8 percent) and in Louisville (18.5 percent).

Table 2 also shows that expenditure weights for rents were appreciably higher in the largest MSAs, but appreciably lower in other MSAs and non-metro areas. In the five largest MSAs, the expenditure weight was 24.3 percent, much larger than for the Eighth District 
MSAs. For example, Los Angeles's housing cost weight was 27.8 percent in 2015. Similarly, New York's housing cost share was 25.3 percent. Rent shares in the Eighth District were also lower than the average of all other MSAs, and rent shares in non-metro areas (14.3 percent) were significantly lower than the average of all MSAs.

Table 2 also lists expenditure weights for non-rent services, such as public transportation and medical services, and goods, such as groceries and apparel. On balance, there is not much discrepancy between non-rent services expenditure shares across the country. The table shows that expenditure weights for non-rent services are roughly 37 percent for most householdswhether in urban or rural areas.

Expenditure weights for goods, however, are a different matter. Table 2 shows that Eighth District MSAs have a higher expenditure weight on goods than the five largest MSAs (37.4 percent) and all other MSAs (41.6 percent). Expenditure weights in the four Eighth District MSAs range from 43.4 percent in St. Louis to 44.2 percent in Louisville. A final takeaway from Table 2 is that non-metro MSAs tend to have much larger expenditure weights for goods: 48.9 percent. In short, rural areas tend to have lower housing costs and as a result spend a greater portion of their income on goods.

The key takeaway from this analysis is that rent is the largest single expenditure share of the nine categories listed in the RPPs, and it varies significantly across regions and MSAs.

\section{COMPARING ST. LOUIS LIVING STANDARDS WITH OTHER MSAs}

According to the BEA, an important function of the RPPs is to adjust measures of nominal income for price level differences across regions and across time. Historically, economists and other analysts have used either the CPI or the PCEPI to deflate measures of nominal income. Now, economic analysts can use the RPPs to show how cost of living variation across states and MSAs matters for determining measures of real incomes at this level of disaggregation.

To see how using RPPs instead of a national, temporal price index matters, let's first look at the data from a regional standpoint. Figure 2 shows the non-cost-of-living adjusted per capita personal income in 2015, while Figure 3 shows each state's per capita personal income deflated by the BEA's RPPs in 2015. Incomes in both maps are adjusted for inflation using the PCEPI. Looking at Figure 2, incomes are highest in the heavily populated areas on the East and West coasts. Unadjusted real incomes in 2015 range from $\$ 31,776$ (Mississippi) to $\$ 67,108$ (Washington, D.C.), a difference of 53 percent. However, once these income levels are deflated by the RPPs (see Figure 3), real per capita personal income in Mississippi rises by 16 percent to almost $\$ 37,000$, while per capita personal income in Washington, D.C., declines by 15 percent to just above $\$ 57,000$. Accounting for cost of living differences thus reduces the real income difference between Mississippi and Washington, D.C., by about one-third (from 53 percent to 36 percent). Figures 2 and 3 also show that real incomes on an RPPadjusted basis rise in the Plains states, the Southeast, and the Midwest, but they are adjusted lower in the Northeast and the Far West. In particular, increases (on an RPP-adjusted basis) are most notable in Mississippi (16 percent), Alabama (15 percent), and Arkansas (14 percent). On an RPP-adjusted basis, real income declines are most prominent in Washington, D.C. (down 15 percent), New York (down 13 percent), and New Jersey (down 12 percent). 


\section{Coughlin, Gascon, Kliesen}

Figure 2

Per Capita Personal Income, 2015 (thousands of 2009 \$)

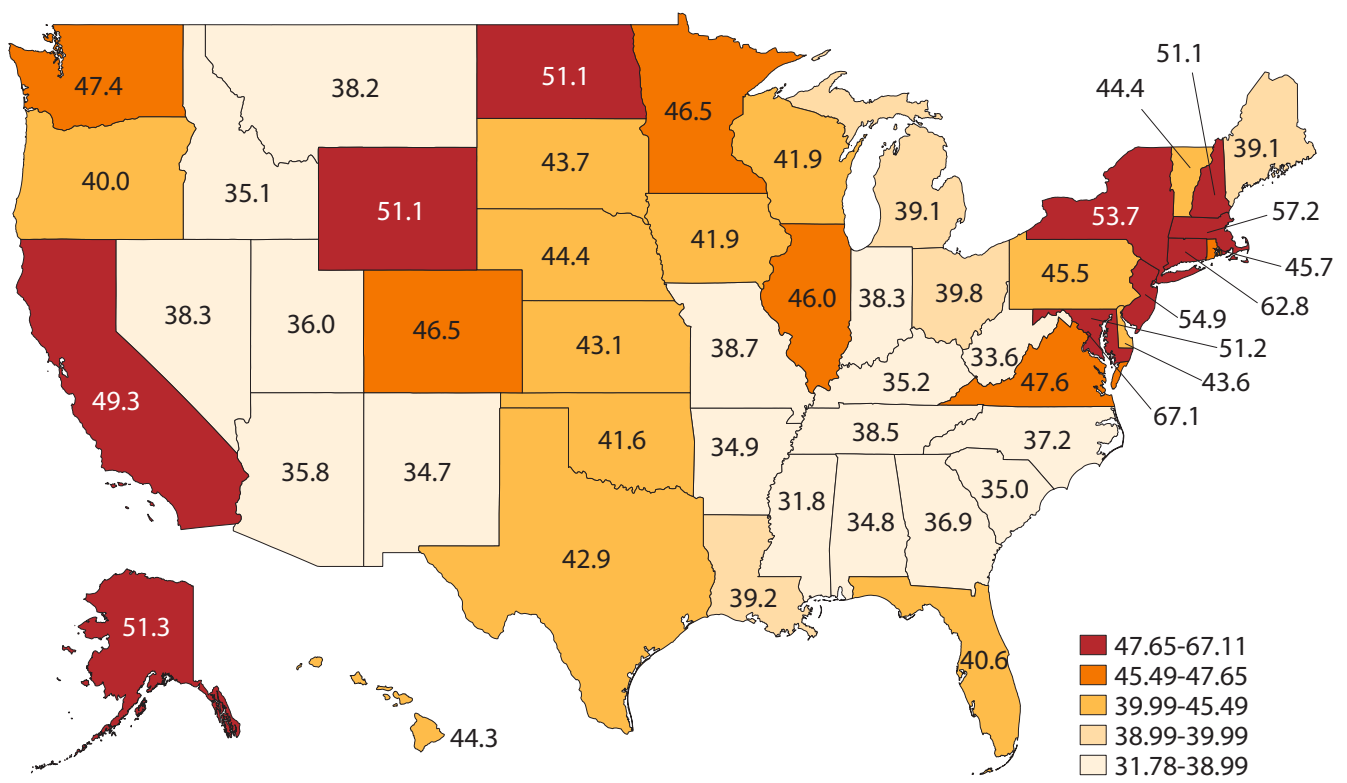

SOURCE: BEA

Figure 3

RPP-Adjusted Per Capita Personal Income, 2015 (thousands of 2009 \$)

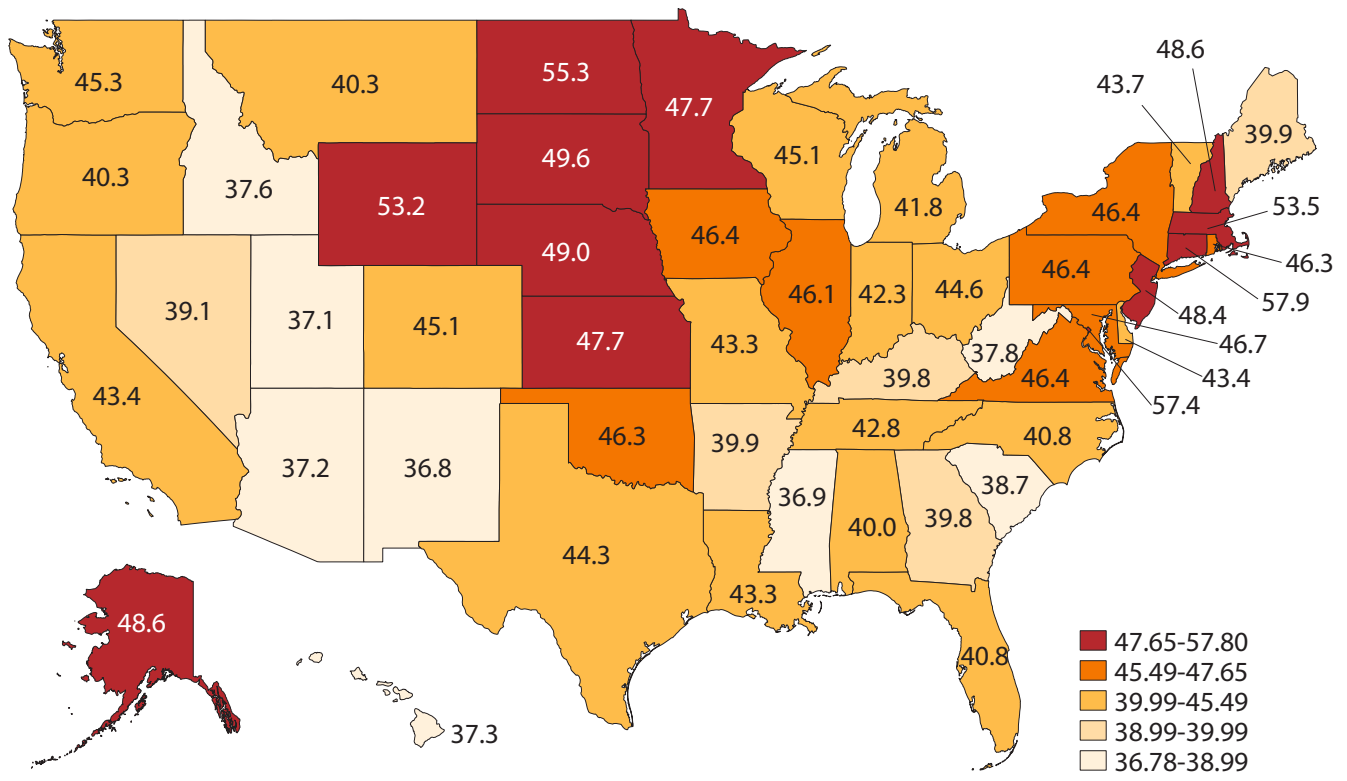

SOURCE: BEA. 
Table 3

The Top 20 Most- and Least-Expensive MSAs According to the RPPs, 2015

\begin{tabular}{|c|c|c|c|c|c|}
\hline \multicolumn{3}{|c|}{ Most expensive } & \multicolumn{3}{|c|}{ Least expensive } \\
\hline MSA & Rank & RPP & MSA & Rank & RPP \\
\hline Urban Honolulu, $\mathrm{HI}$ & 1 & 124.5 & Gadsden, AL & 362 & 84.5 \\
\hline San Jose, CA & 2 & 124.1 & Cleveland, TN & 363 & 84.4 \\
\hline Santa Cruz, CA & 3 & 122 & Dalton, GA & 364 & 84.2 \\
\hline New York, NY & 4 & 121.9 & Anniston, AL & 365 & 84.1 \\
\hline San Francisco, CA & 4 & 121.9 & Brownsville, TX & 366 & 84.0 \\
\hline Bridgeport, CT & 6 & 120.1 & Carbondale, IL & 367 & 83.9 \\
\hline Napa, CA & 6 & 120.1 & Albany, GA & 368 & 83.8 \\
\hline Washington, DC & 8 & 119.1 & Florence, AL & 368 & 83.8 \\
\hline Santa Rosa, CA & 9 & 118.5 & Pine Bluff, AR & 370 & 83.5 \\
\hline Los Angeles, CA & 10 & 117.6 & Cape Girardeau, MO & 371 & 82.7 \\
\hline San Diego, CA & 11 & 116.6 & Hattiesburg, MS & 372 & 82.6 \\
\hline Oxnard, CA & 12 & 116.1 & Jefferson City, MO & 373 & 82.4 \\
\hline Vallejo, CA & 13 & 115.9 & Jackson, TN & 374 & 82.1 \\
\hline New Haven, CT & 14 & 112.1 & Jonesboro, AR & 375 & 81.9 \\
\hline Trenton, NJ & 15 & 112 & Sebring, FL & 375 & 81.9 \\
\hline Boston, MA & 16 & 110.3 & Morristown, TN & 377 & 81.3 \\
\hline Boulder, CO & 17 & 110.1 & Danville, IL & 378 & 81.2 \\
\hline Seattle, WA & 18 & 109.4 & Valdosta, GA & 379 & 81.1 \\
\hline Santa Maria, CA & 18 & 109.4 & Rome, GA & 380 & 80.2 \\
\hline Anchorage, AK & 18 & 109.4 & Beckley, WV & 381 & 79.7 \\
\hline \multicolumn{6}{|c|}{ NOTE: U.S. average - all areas $=100}$. \\
\hline \multicolumn{6}{|l|}{ Source: BEA. } \\
\hline
\end{tabular}

The BEA also publishes RPPs for the 381 MSAs. Table 3 lists the 20 most- and leastexpensive MSAs, as measured by their RPPs. The most expensive MSAs are those dominated by large cities on the East and West coasts that also have relatively high average levels of nominal income. Individuals who live and work in these high-cost cities must be compensated for the higher prices charged for many goods and services. Of the 20 MSAs with the highest RPPs, half are in California. By contrast, the least-expensive cities tend to be more geographically dispersed and in less populous areas. For example, the least-expensive MSA is Beckley, West Virginia, located near the Appalachian mountains, followed by Rome and Valdosta, Georgia (in the South), and Danville, Illinois (in the Midwest). $\underline{21}$ With an RPP of 124.5, the prices of goods and services in Honolulu in 2015 were 24.5 percent higher than the national average and 56.6 percent higher than Beckley, West Virginia. Table 3 thus suggests that there is a positive correlation between an MSA's population and its RPP. Figure 4 provides further evidence of this relationship by plotting the RPP for all items and the log of the population of MSAs in 
Figure 4

RPP and Population for All MSAs, 2015

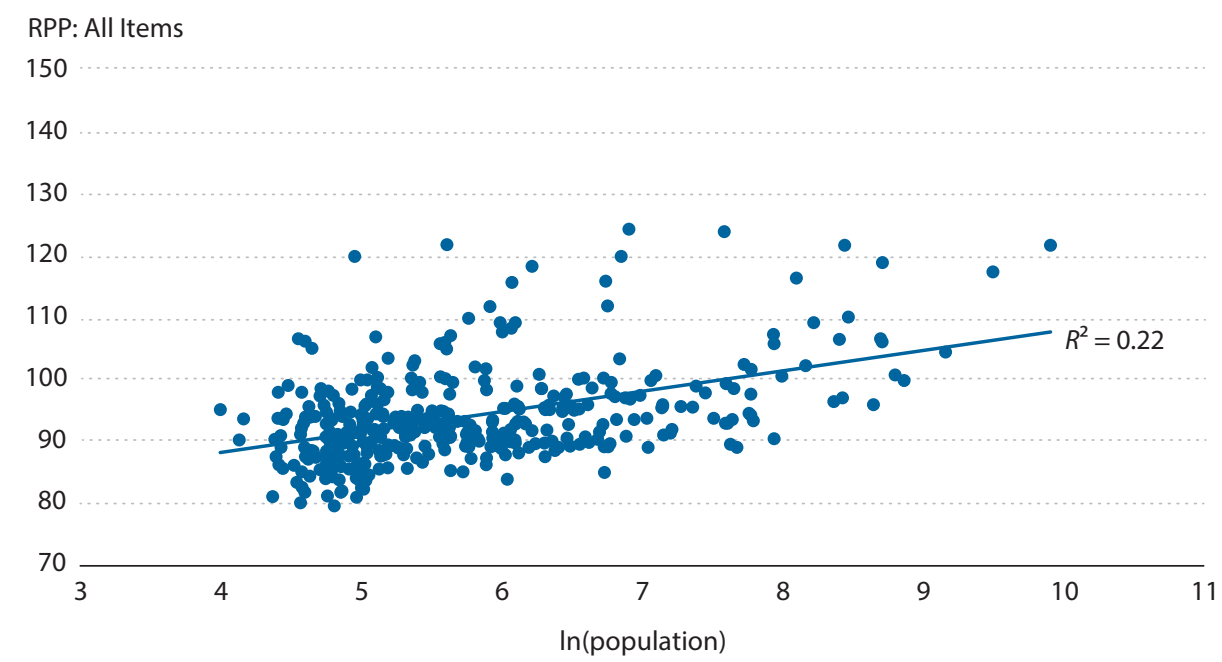

SOURCE: Census Bureau and BEA.

2015. The figure shows that this correlation is positive. However, as the scatter plot suggests, the size of this correlation is perhaps not as large as Table 3 would suggest.

St. Louis and many other Eighth District MSAs have RPPs that are below 100, which means that their prices, on average, are lower than the national average. Indeed, six of the 20 least-expensive MSAs are located in the Eighth District: Jonesboro, Arkansas (ranked 375th); Jackson, Tennessee (374th); Jefferson City, Missouri (373rd); Cape Girardeau, Missouri (371st); Pine Bluff, Arkansas (370th); and Carbondale, Illinois (367th).

Table 4 shows RPPs for the St. Louis, Memphis, Louisville, and Little Rock MSAs in 2009 and 2015. The table includes three national benchmarks for comparison: the U.S. average (including both MSAs and non-metro areas), the average of only MSAs, and the median metro area. The U.S. average serves Table 4

Eighth District RPPs, 2009 and 2015 as the broadest benchmark, but may be misleading given that there is evidence that MSAs have higher costs than nonmetro areas. This leads to our second measure, the population-weighted average for MSAs only. Because there is a positive correlation between population and cost of living, both these average benchmarks tend to be skewed upward, as the 10 largest MSAs comprise 26 percent of the national

\begin{tabular}{lrr} 
MSA & $\mathbf{2 0 0 9}$ & $\mathbf{2 0 1 5}$ \\
\hline St. Louis, MO & 88.6 & 90.6 \\
Memphis, TN & 92.5 & 91.5 \\
Louisville, KY & 91.6 & 91.2 \\
Little Rock, AR & 91.8 & 90.9 \\
\hline U.S. average-all areas & 100.0 & 100.0 \\
MSA average & 102.3 & 101.7 \\
MSA median & 93.7 & 93.0 \\
& & \\
Source: BEA. & & \\
\hline
\end{tabular}


population and 31 percent of the metro area population. Our third measure, the median MSA, is an alternative benchmark that accounts for this skewed distribution. In both 2009 and 2015, the U.S. MSA average RPP exceeded the MSA median RPP. In other words, the highly populated, high-cost areas on the coasts lift the average RPP above the median RPP.

The four largest Eighth District MSAs have RPPs below the national average. In 2015, St. Louis's RPP was 90.6, which was about 9 percent below the national average. Little Rock's RPP (90.9) was very close to St. Louis's, with Louisville's (91.2) and Memphis's (91.5) slightly higher. The median MSA in the nation had an RPP of 93.0, indicating the Eighth District cities were closer to the median MSA than to the average MSA.

Trends over time generally follow the median MSA as well. St. Louis's RPP has increased modestly since 2009, while the other three District MSA RPPs have decreased modestly. Thus, from 2009 to 2015, prices in St. Louis have trended closer to the national average, while prices in the median MSA and the other three District MSAs have diverged modestly further from the national average.

\subsection{Measuring Eighth District Living Standards}

Table 5 shows real standards of living in the four largest Eighth District MSAs as measured by real per capita personal income and real median household income. The top half of Table 5 shows nominal incomes that have been deflated using the national PCEPI but not adjusted for cost of living. The bottom half of the table deflates these two income measures by each MSA's RPP.

These real adjusted incomes reflect a truer measure of purchasing power than those deflated only by the PCEPI. For example, St. Louis's PCEPI-deflated per capita personal income was $\$ 44,715$ in 2015 , but was 10.9 percent higher, $\$ 49,598$, when also deflated by the RPP. Accordingly, St. Louis's per capita personal income ranking jumped from 67th on an unadjusted basis to 20th on an RPP-adjusted basis. RPP-adjusted incomes also rose in the other three MSAs relative to those not adjusted by the RPP. For instance, Louisville's ranking rose 32 spots (from 120th to 88th), Little Rock's ranking rose 16 spots (from 197th to 181st), and Memphis's ranking rose 22 spots (from 171th to 149th). In terms of median household income, St. Louis's ranking rose from 100th on an unadjusted basis to 61st once adjusted for the MSA's cost of living. Both Little Rock's and Louisville's RPP-adjusted median household income ranking rose relative to the unadjusted measured, with Little Rock's rising from 226th to 215 th and Louisville from 151st to 119th. Meanwhile, Memphis's ranking was virtually unchanged, falling from 234th to 235th.

Both the national and MSA average income measures tend to be above the median MSA income. As seen in Table 5, income among Eighth District MSAs is generally higher than the median MSA, regardless of which measure of income we use or whether or not we adjust for cost of living. In other words, standards of living in these four Eighth District MSAs are high compared with their peer regions.

Comparisons against the average benchmarks are mixed. With neither measure of income adjusted for cost of living, in St. Louis in 2015, both measures were between the national and MSA averages, while incomes in Memphis, Louisville, and Little Rock were below both the 


\section{Coughlin, Gascon, Kliesen}

\section{Table 5}

Eighth District Measures of Income (Chained 2009 \$)

\begin{tabular}{|c|c|c|c|c|c|c|c|c|c|c|}
\hline \multirow[b]{3}{*}{ MSA } & \multicolumn{10}{|c|}{ Not adjusted for RPPs } \\
\hline & \multicolumn{5}{|c|}{ Per capita personal income } & \multicolumn{5}{|c|}{ Median household income } \\
\hline & 2009 & Rank & 2015 & Rank & $\begin{array}{l}\text { Percent } \\
\text { change }\end{array}$ & 2009 & Rank & 2015 & Rank & $\begin{array}{l}\text { Percent } \\
\text { change }\end{array}$ \\
\hline St. Louis, MO & $\$ 41,289$ & 58 & $\$ 44,715$ & 67 & $1.4 \%$ & $\$ 51,691$ & 99 & $\$ 51,568$ & 100 & $0.0 \%$ \\
\hline Memphis, TN & $\$ 36,072$ & 149 & $\$ 38,619$ & 171 & $1.2 \%$ & $\$ 43,633$ & 244 & $\$ 44,301$ & 234 & $0.3 \%$ \\
\hline Louisville, KY & $\$ 36,424$ & 144 & $\$ 40,679$ & 120 & $1.9 \%$ & $\$ 46,786$ & 168 & $\$ 48,295$ & 151 & $0.5 \%$ \\
\hline Little Rock, AR & $\$ 36,676$ & 140 & $\$ 37,489$ & 197 & $0.4 \%$ & $\$ 45,967$ & 188 & $\$ 44,796$ & 226 & $-0.4 \%$ \\
\hline U.S. average_-all areas & $\$ 39,376$ & & $\$ 43,996$ & & $2.0 \%$ & $\$ 50,221$ & & $\$ 50,921$ & & $0.2 \%$ \\
\hline MSA average & $\$ 40,897$ & & $\$ 45,488$ & & $1.9 \%$ & $\$ 54,080$ & & $\$ 54,586$ & & $0.2 \%$ \\
\hline MSA median & $\$ 34,513$ & & $\$ 37,824$ & & $1.6 \%$ & $\$ 45,811$ & & $\$ 46,659$ & & $0.3 \%$ \\
\hline
\end{tabular}

\begin{tabular}{|c|c|c|c|c|c|c|c|c|c|c|}
\hline \multirow[b]{3}{*}{ MSA } & \multicolumn{10}{|c|}{ Adjusted for RPPs } \\
\hline & \multicolumn{5}{|c|}{ Per capita personal income } & \multicolumn{5}{|c|}{ Median household income } \\
\hline & 2009 & Rank & 2015 & Rank & $\begin{array}{l}\text { Percent } \\
\text { change }\end{array}$ & 2009 & Rank & 2015 & Rank & $\begin{array}{l}\text { Percent } \\
\text { change }\end{array}$ \\
\hline St. Louis, MO & $\$ 46,872$ & 14 & $\$ 49,598$ & 20 & $1.0 \%$ & $\$ 58,342$ & 36 & $\$ 56,918$ & 61 & $-0.4 \%$ \\
\hline Memphis, TN & $\$ 39,229$ & 141 & $\$ 42,430$ & 149 & $1.4 \%$ & $\$ 47,171$ & 238 & $\$ 48,417$ & 235 & $0.4 \%$ \\
\hline Louisville, KY & $\$ 39,983$ & 120 & $\$ 44,796$ & 88 & $2.0 \%$ & $\$ 51,076$ & 149 & $\$ 52,955$ & 119 & $0.6 \%$ \\
\hline Little Rock, AR & $\$ 40,196$ & 112 & $\$ 41,444$ & 181 & $0.5 \%$ & $\$ 50,073$ & 173 & $\$ 49,281$ & 215 & $-0.3 \%$ \\
\hline U.S. average-all areas & $\$ 39,376$ & & $\$ 43,996$ & & $2.0 \%$ & $\$ 50,221$ & & $\$ 50,921$ & & $0.2 \%$ \\
\hline MSA average & $\$ 40,000$ & & $\$ 44,652$ & & $1.9 \%$ & $\$ 52,589$ & & $\$ 53,410$ & & $0.3 \%$ \\
\hline MSA median & $\$ 37,385$ & & $\$ 41,051$ & & $1.6 \%$ & $\$ 49,041$ & & $\$ 50,140$ & & $0.4 \%$ \\
\hline
\end{tabular}

NOTE: Percent changes are annualized.

SOURCE: BEA, BLS, and authors' calculations.

national and MSA averages. On an RPP-adjusted basis, per capita personal income in St. Louis jumped from 1.6 percent above the national average to 12.7 percent above the national average. Median household income in St. Louis jumped from 1.3 percent above the national average to 11.8 percent above. The RPP adjustment moved Louisville from 7.5 percent below to 1.8 percent above the national average for per capita personal income and from 5.2 percent below to 4.0 percent above the national average for median household income. RPP-adjusted median household income for Louisville $(\$ 52,955)$ was 0.9 percent below the average MSA level $(\$ 53,410)$ and 5.6 percent above the median MSA level $(\$ 50,140)$. Conversely, the lower cost of living was not enough to push living standards-by either measure of real income-in Little Rock or Memphis above the national average. 


\section{RPPs as Preferred Cost of Living Measure}

Why has per capita income increased faster than median household income? (See the figure.) A number of reasons explain this observation. First, employer-provided benefits, which are excluded from household income, but included in personal income, have been increasing faster than total compensation. Second, the number of households has been growing more rapidly than the population. This implies people are forming households with fewer people, such as individuals living alone. Therefore, even if the measure of income were the same between the two statistics, household income growth would be slower than personal income growth. Third, income inequality has increased. Personal income is an average, while household income is the median. As the income shares of those at the top of the income distribution have increased, average income has increased relative to median income.

For additional details on this issue, see Fitzgerald (2008) and a Federal Reserve Bank of St. Louis (2016) blog post.

\section{Real Income Growth, 1984:Q1-2017:Q1}

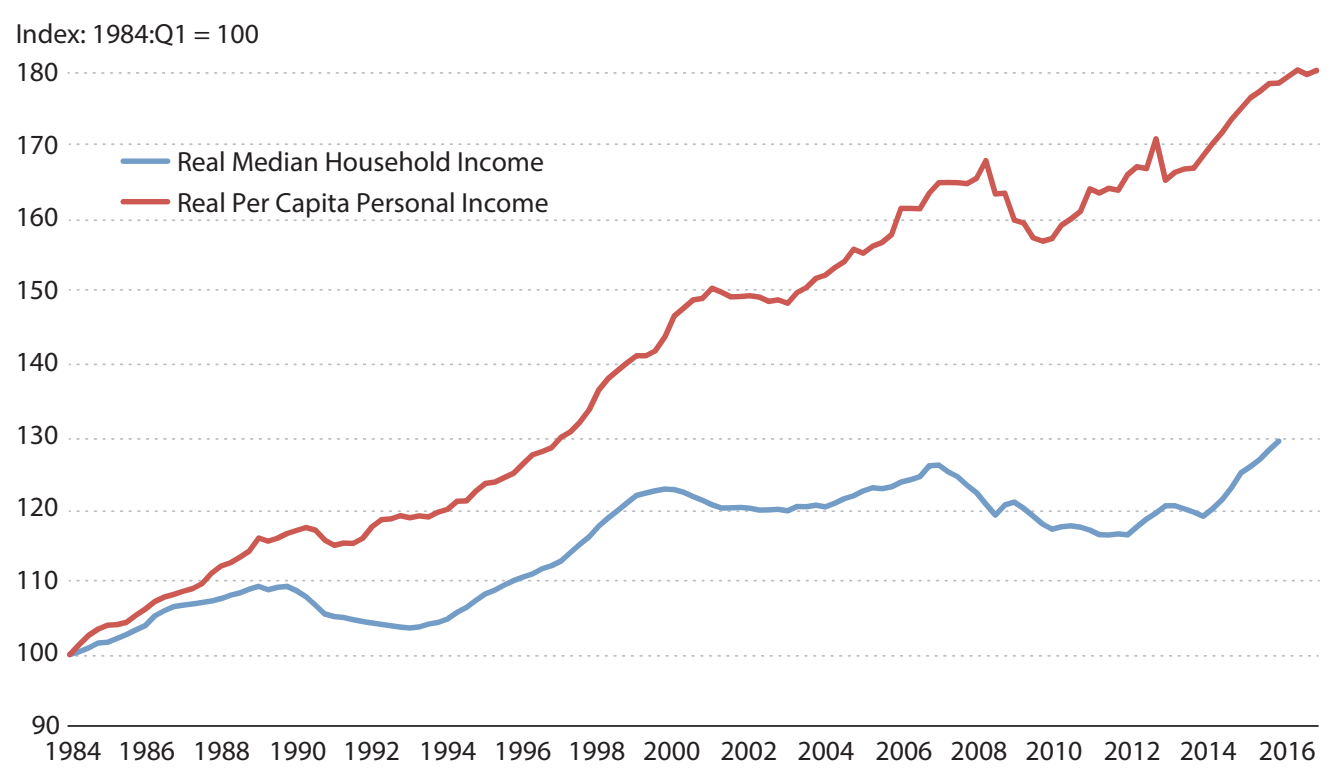

SOURCE: BEA, Census Bureau, and FRED.

\subsection{Changes in Eighth District Living Standards Since 2009}

The levels of real income adjusted for cost of living differences across MSAs help to gauge current living standards, but it is nonetheless useful to examine how these living standards have changed since the end of the Great Recession in 2009. In St. Louis, economic growth has lagged behind both the national average as well as the median MSA. Real per capita personal income (RPP-adjusted) increased at an annual rate of 1.0 percent from 2009 to 2015; however, median household income declined at a 0.4 percent annual rate over this period. (See the boxed insert for a discussion of why per capita personal income has generally grown faster than median household income.) By contrast, Louisville has experienced appreciably stronger 


\section{Coughlin, Gascon, Kliesen}

growth by both measures. Over this six-year period, Louisville's real per capita personal income growth rate of 2.0 percent per year was on par with the national average (also 2.0 percent) but outpaced the median MSA growth of 1.6 percent. Similarly, Louisville's median household income has grown 0.6 percent per year, or about two times the rate of the national benchmarks.

For Little Rock and Memphis, income growth is also slow. In both MSAs, the annualized growth rates lagged behind the national benchmarks when adjusted for cost of living differences. Little Rock's real per capita personal income grew just 0.5 percent per year since 2009, by far the slowest growth rate for this measure of income of the four District MSAs.

\section{EXPECTED CHANGES IN LIVING STANDARDS}

Analysts often use past trends to shape an economic narrative on what the future may hold. In many cases, extrapolating current growth trends can serve as a useful (and reasonable) forecast of future growth. This is particularly true in cases when the fundamental factors driving growth do not change much over time. For example, population growth tends to be primarily driven by fertility rates, which thus determine the average age of the population over time. In fact, as shown in Figure 5A, just over half of the variation in regional population growth over the past 15 years (2001-2015) can be predicted by using population growth rates from the 15 years prior (1985-2000).

The same cannot be said for predicting changes in incomes. Economic theory holds that productivity growth is crucial for determining changes in real incomes over time. Economists typically define productivity as measured output per unit of input, where output is real gross domestic product or gross state product and the unit of input is hours worked. Measuring productivity is often difficult because it depends on many factors, such as technology embedded in the nation's capital stock, the knowledge and skills of the workforce, and government policies that promote or restrict the most efficient allocation of economic resources. In short, a nation's, state's, or MSA's economic growth will be the sum of its population growth and its productivity growth.

Economic theory and historical trends suggest that the factors driving income growth can change considerably over time. To see this, Figure 5B plots real per capita income growth for MSAs over two periods: 1985 to 2000 and 2001 to 2015. If there were persistence in the data-that is, if economic growth in the two periods were of the same sign and similar in magnitude-a regression line drawn through the observations would have a positive slope. However, that is not what the data show. First, the historical correlation between past and future growth is slightly negative, which indicates that regions where incomes were growing relatively fast between 1985 and 2000 had incomes that grew relatively slower between 2001 and 2015. Second, the differences in past per capita growth rates explain only 9 percent of the differences in future growth. As such, we should use caution when using simple trend extrapolation methods to predict future income growth. Instead, policymakers would be wise to focus on the fundamentals - that is, productivity growth and its determinants $\underline{22}$ — when designing policies to boost economic growth. 


\section{Figure 5}

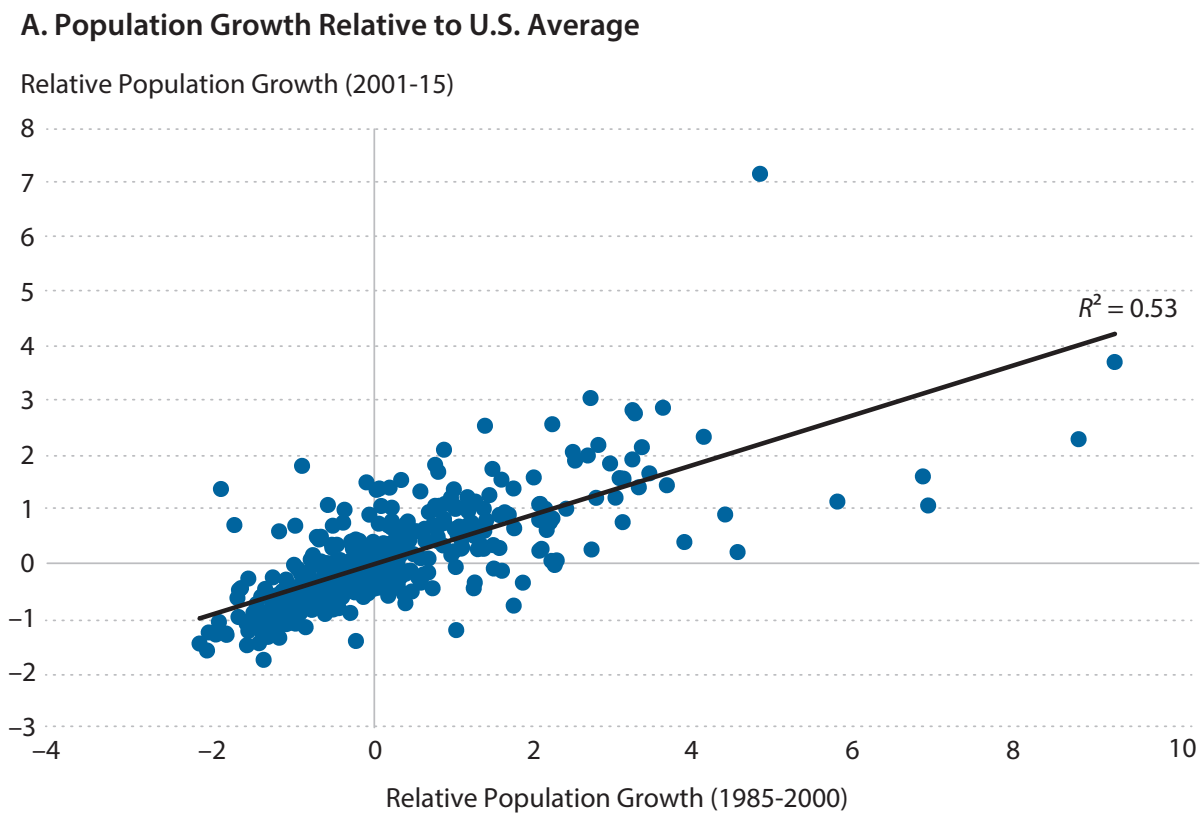

\section{B. Per Capita Personal Income Growth Relative to U.S. Average}

Relative PCPI Growth (2001-15)

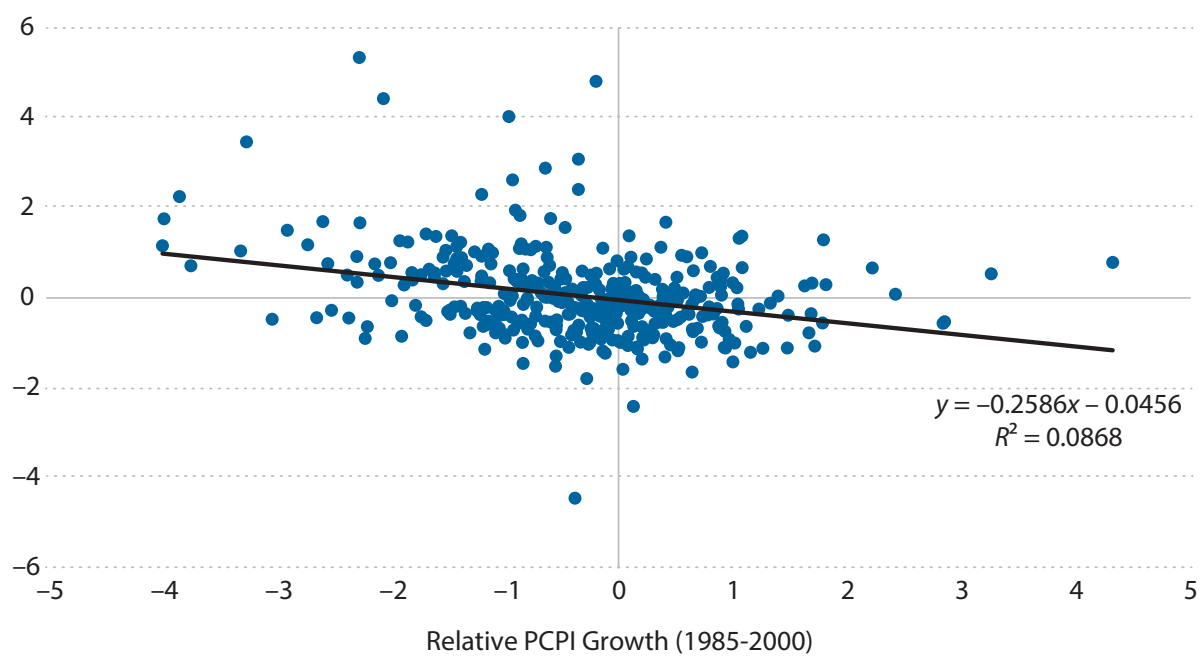

NOTE: Relative growth is the difference between the MSA growth rate and the national rate. SOURCE: BEA. 


\section{CONCLUSION}

The economic health of a region is not easily summarized in a single statistic, as each indicator provides insight into different aspects of the economy. Our analysis attempts to analyze the economic performance of the major Eighth Federal Reserve District MSAs in a simple yet fundamentally sensible way: measuring economic well-being as income adjusted for cost of living differences. Importantly, this method, while conventional, is often overlooked in regional analysis. The overall picture that emerges from the analysis in this article is that living standards in the St. Louis MSA are high compared with national averages, while living standards in Louisville, Little Rock, and Memphis are generally in-line with national averages and above the median MSA.

Although the level of real income is a good measure of current living standards, income growth rates are also of great importance and describe the evolution of living standards over time. To the extent that incomes continue to evolve in the same manner, they may provide insight into where incomes will be in the future. Since the end of the Great Recession, St. Louis, Memphis, and Little Rock have grown more slowly than the nation, while Louisville's growth has outpaced the national average.

The slow growth of living standards is consistent with other metrics, such as real GDP per capita and employment. The primary concern with slow growth rates is that they could continue into the future, and the relatively high standards of living in places such as St. Louis would continue to erode. In this case, real per capita personal income in St. Louis would be at the national average within the next decade. However, recent data show limited persistence of income growth over the past decade, suggesting that, for the near future, high standards of living in St. Louis and elsewhere in the Eighth District are here to stay. 


\section{NOTES}

1 See, for example, recent articles by The Economist (2017) and Longman (2015).

2 An MSA includes a principal city and surrounding areas. For a detailed definition, see https://www.census.gov/ programs-surveys/metro-micro/about.html.

$\underline{3}$ The Eighth Federal Reserve District includes all of Arkansas, eastern Missouri, southern Illinois and Indiana, western Kentucky and Tennessee, and northern Mississippi. The Eighth District headquarters is in St. Louis, and the branch offices are in Little Rock, Louisville, and Memphis.

4 Moretti (2013) has shown that adjusting for cost of living differences across MSAs provides valuable insights for wage inequality between skilled and unskilled workers.

5 An economy's future growth will depend critically on the productivity of its labor and capital inputs, and other key factors. Economists typically define productivity as output produced per hour worked. Although vitally important, this paper will largely abstract from this issue.

6 Admittedly, one's quality of life depends on more than one's real income. Many additional factors are associated with geographic location, such as weather, commuting time, natural amenities (e.g., mountains and oceans), the tax and regulatory environment, and government-provided amenities (e.g., parks/recreation facilities).

$\geq$ We are ignoring consumption that is financed from one's wealth (past income not spent).

8 This is termed the Haig-Simons definition of income. See Slemrod and Bakija (1996, p. 32).

9 Another distinction is between pre- and after-tax income levels. Compared with national data, data availability and timeliness at the MSA level can be an issue. For example, total compensation is available at the national level but not at the MSA level. Likewise, individual income tax data are available at the MSA level, but only with a significant lag.

10 If incomes were distributed symmetrically, then median and mean incomes would be equal. For a skewed distribution, however, the median is likely a preferred measure because it is less affected by outliers and extreme values.

11 Generally speaking, the average of prices of goods and services tend to rise over time (e.g., the all-items consumer price index, or $\mathrm{CPI})$.

12 We are ignoring problems related to accurately measuring prices, such as quality changes or the incorporation of new goods and services. See Feldstein (2017) for a more detailed discussion.

$\underline{13}$ Income changes can also cause changes in a consumer's expenditure pattern.

14 At a highly simplistic level, the agencies construct price indexes by (i) determining the expenditure share of a basket of goods and services consumed by the average household (weights); (ii) collecting prices for these goods and services; and then (iii) multiplying the prices and the weights together to form an index. For more information about CPI methodology, see the Bureau of Labor Statistics (BLS) Handbook of Methods (2015).

15 The RPPs are available from 2008 to 2015. In our analysis, we use the data from 2009 to 2015 to focus on the recovery from the Great Recession. Ideally, we would have used a longer time period that captures a complete business cycle, but the lack of RPPs prior to 2008 precluded this option. The magnitude of the recessionary shock varied across MSAs, so the size of the potential bounceback could be affecting our results.

16 At the national level, household expenditures on housing goods and services (shelter, fuels and utilities, and furnishings) as a share of income has remained relatively constant over the past 10 years. In 2005, two-thirds of households owned their own home-either outright or with a mortgage. All households, whether owners or renters, devoted one-third of their income to total household expenditures. By 2015, the share of owners who owned their own home had declined to 62 percent, but the expenditure share on housing remained at 33 percent.

17 Moretti (2012) argues that a significant part of the wealth created in innovation hubs such as Austin, Texas, Boston, Massachusetts, and the Silicon Valley area of California is accrued through rising property values (in addition to labor compensation). This benefits existing homeowners, but not necessarily renters, since their higher earnings are offset by higher rent costs.

18 Research by Handbury and Weinstein (2015) suggests that the variation observed in regional price indexes is primarily due to measurement error. 


\section{Coughlin, Gascon, Kliesen}

19 Our analysis uses two income measures, per capita personal income and median household income, which are adjusted by prices. For many important policy issues, one needs additional information on the distribution of income and the distribution of prices. For example, see Edmiston (2016) for an analysis of rent affordability for low- and moderate-income households across MSAs.

20 For those owners without a mortgage, the housing cost is the estimate of what the owner would have to pay to rent their house, which is termed owners' equivalent rent.

21 In 2015, the median population of the MSAs with the 20-highest RPPs was 853,000, while the median population of the MSAs with the 20-lowest RPPs was about 125,000.

22 Glaeser and Gottlieb (2009) find that education in particular is an important source of productivity growth in cities.

\section{REFERENCES}

Aten, Bettina H.; Figueroa, Eric B. and Martin, Troy M. "Regional Price Parities for States and Metropolitan Areas, 2006-2010." Survey of Current Business, August 2012, pp. 229-42.

Bureau of Labor Statistics. "The Consumer Price Index" in Handbook of Methods. Chap. 17. June 2015; https://www.bls.gov/opub/hom/pdf/homch17.pdf.

Council for Community and Economic Research. "Cost of Living Index Manual." December 2015.

Edmiston, Kelly D. "Residential Rent Affordability across U.S. Metropolitan Areas." Federal Reserve Bank of Kansas City Economic Review, Fourth Quarter 2016, pp. 5-27.

Federal Reserve Bank of St. Louis. "The Puzzle of Real Median Household Income." The FRED Blog, December 1, 2016; https://fredblog.stlouisfed.org/2016/12/the-puzzle-of-real-median-household-income.

Feldstein, Martin. "Underestimating the Real Growth of GDP, Personal Income, and Productivity." Journal of Economic Perspectives, Spring 2017, 32(2), pp. 145-64; https://doi.org/10.1257/jep.31.2.145.

Fitzgerald, Terry J. "Where Has All the Income Gone?" Federal Reserve Bank of Minneapolis The Region, September 2008, pp. 24-29, 50-57.

Glaeser, Edward L. and Gottlieb, Joshua D. "The Wealth of Cities: Agglomeration Economies and Spatial Equilibrium in the United States." Journal of Economic Literature, December 2009, 47(4), pp. 983-1028; https://doi.org/10.1257/jel.47.4.983.

Handbury, Jessie and Weinstein, David E. "Goods Prices and Availability in Cities." Review of Economic Studies, 2015, 82(1), pp. 258-96; https://doi.org/10.1093/restud/rdu033.

Longman, Phillip. "Why the Economic Fates of America's Cities Diverged." The Atlantic, November 28, 2015.

Moretti, Enrico. The New Geography of Jobs. New York: Houghton Mifflin Harcourt Publishing Company, 2012.

Moretti, Enrico. "Real Wage Inequality." American Economic Journal: Applied Economics, January 2013, 5(1), pp. 65-103; https://doi.org/10.1257/app.5.1.65.

Olsen, Edgar, Early, Dirk W. and Carrillo, Paul. "A Panel of Price Indices for Housing, Other Goods, and All Goods for All Areas in the United States 1982-2008." Virginia Economics Online Papers, University of Virginia Department of Economics, December 2010.

Slemrod, Joel and Bakija, Jon. Taxing Ourselves: A Citizen's Guide to the Great Debate Over Tax Reform. Cambridge, MA: MIT Press, 1996.

The Economist. "Millennials Really Like St. Louis.” April 12, 2017. 